Article

\title{
Discourses across Scales on Forest Landscape Restoration
}

\author{
Sabine Reinecke * and Mareike Blum \\ Chair Group of Forest and Environmental Policy, University of Freiburg, 79106 Freiburg, Germany; \\ mareike.blum@ifp.uni-freiburg.de \\ * Correspondence: sabine.reinecke@ifp.uni-freiburg.de; Tel.: +49-761-203-3717
}

Received: 31 October 2017; Accepted: 20 February 2018; Published: 27 February 2018

\begin{abstract}
Forest Landscape Restoration (FLR) has recently received broad political support, e.g., under the Bonn Challenge. However, although the concept promises quadruple wins for humans, biodiversity as well as climate change mitigation and adaptation, it remains heavily underutilized in practice. Drawing on a social constructivist reading and a survey in different developing and developed countries, we elaborate on varying existing narratives about FLR at global and country level. Overall, we find that FLR understandings in different countries strongly resonate with the globally pursued idea of enhancing ecological and human well-being. In more detail, however, rural development and climate mitigation oriented motives are prioritized over aspects of species conservation or adaptation. Globally, strong emphasis is placed on collaborative processes empowering local actors. At country level, by contrast, these ideas regarding greater local authority are complemented with a techno-managerial notion of government control. Considering the potential power struggles that could be evoked from such dialectic expectations, we see it as a primary responsibility for global FLR processes to fully embrace the political dimension of FLR and to support conflict resolution and adaptive learning processes.
\end{abstract}

Keywords: forest landscape restoration; mitigation; adaptation; sustainable development; discourse analysis

\section{Introduction}

Forest Landscape Restoration (FLR) has received much political attention recently for its role in tackling multiple societal challenges, including climate change mitigation and adaptation, food security and biodiversity loss. Particularly through the Bonn Challenge and partners such as the Convention on Biological Diversity (CBD), the International Union for Conservation of Nature (IUCN) or the World Resources Institute (WRI), the topic was elevated onto the international agenda [1]. The Bonn Challenge is a multi-stakeholder initiative founded in 2011 and based on the informal declaration of intent "to restore 150 million hectares of the world's deforested and degraded lands by 2020" and another 200 million by 2030 [2]. It links to the New York Declaration on Forests [3] and regional political initiatives in Africa and Latin America and offers an exchange platform for interested countries as well as non-state actors to demonstrate leadership in implementing FLR.

FLR is a promising approach with potential to bring about "quadruple wins", thereby meeting different environmental and development targets. Principally, it allows countries to simultaneously: (i) mitigate and (ii) adapt to climate change in a way that enhances (iii) local livelihoods and contributes to sustainable development, while at the same time (iv) halting the loss of and conserving biodiversity [4-9]. FLR thus provides an opportunity for countries to fulfill multiple commitments to different international agreements, including e.g., the CBD, the United Nations Framework Convention on Climate Change (UNFCCC) or the Sustainable Development Goals (SDGs) as well as the New York 
Declaration on Forests [3]. Given a gigantic restoration potential of 2 billion hectares globally [2,10], FLR may help to achieve higher ambitions as declared under the Paris Agreement towards $1.5{ }^{\circ} \mathrm{C}$, so long as restored landscapes continue to be used sustainably [6].

In the last decade, forest restoration has played a role in fulfilling political commitments under the UNFCCC or the Kyoto Protocol, e.g., through afforestation and reforestation (A/R) projects under the Clean Development Mechanism (CDM) of the Kyoto Protocol or more recently through the "carbon stock enhancement" or "degradation" related activities under REDD+. However, despite the multiple benefits of standing forests for the climate, biodiversity and people [4,7-9], the existing restoration potential remains heavily underutilized in practice. One related issue is that climate effective A/R projects under the CDM may favor large-scale (industrial) plantations that are associated with numerous environmental and social risks [11-13]. Another more central issue is the high degree of objection from local people to such changes, presenting an obstacle for mechanisms such as the CDM and REDD+. Earlier studies show that local people have seen political instruments as another attempt at colonization and commodification of natural resources [14-16]. Evidently, the local on-the-ground experience of these projects is a key factor for the longevity of restoration $[9,17]$.

The Bonn Challenge acknowledges that for successful implementation, projects need to integrate different stakeholder desires and realities from national to local levels $[2,18]$. However, little is known about what FLR really means in different contexts and what diverse stakeholders expect from it. Beyond some very recent contributions focused mainly on the international discussions around FLR $[5,19]$, it remains largely under-investigated how receptive national contexts are to the ambitious ideas behind the Bonn Challenge. To assure political practicability of the global landscape initiatives and avoid objection on the ground, it is thus helpful to understand what different stakeholders actually desire from FLR.

Following a social-constructivist line of argumentation and departing from the global discursive center surrounding landscape restoration, e.g., the Bonn Challenge, this paper will illuminate different existing FLR narratives from global to local levels and trace how different meanings of FLR relate to, or potentially even compete with, each other. Specifically, we investigate different understandings of FLR related to the varying objectives pursued, be they climate change mitigation and adaptation, local livelihoods and/or biodiversity. We discuss whether specific understandings may evoke resistance to implementation and undermine the current global ambitions relating to the Bonn Challenge. In this way, we gain practical insights into how the Bonn Challenge and related initiatives may be more responsive to the political realities in different countries.

\section{Background: Forest Landscape Restoration, the Bonn Challenge and the Global Partnership on Forest and Landscape Restoration}

Ideas of rehabilitating forest landscapes in degraded lands for the benefit of humans and the environment are neither new nor unprecedented (cf. [20-22]). Against the backdrop of high contention about when land is actually "degraded, damaged or destroyed" ([23], p. 3), the current global understanding of FLR carries a strong procedural notion. The term was coined around the year 2000 through the work of the Society for Ecological Restoration (SER) [5,24]. In this reading, FLR broadly refers to "a planned process that aims to regain ecological integrity and enhance human well-being in deforested or degraded landscapes" ([25], p. 268).

\subsection{Human and Ecological Well-Being}

Together with the WRI and IUCN, the Global Partnership on Forest and Landscape Restoration (GPFLR) understands FLR as "a long-term process" focused "on strengthening the resilience of landscapes and creating future options to adjust and further optimize ecosystem goods and services as societal needs change or new challenges arise" [4]. This definition by GPFLR is drawn on and referred to globally in various political and academic contexts ([5], p. 1, [14,26]) and strongly informs the work of the Bonn Challenge [2]. 
The GPFLR hosted by IUCN provides the major organizational infrastructure for the Bonn Challenge including the website, meeting facilitation, publications, and capacity building [2,27]. Strategically, GPFLR and hence the Bonn Challenge builds on a growing network of partners from governments, international organizations, academia as well as civil society organizations and individuals [2].

The current notion of FLR broadly corresponds with the work of the Ecological Society of America on "Earth Stewardship" (cf. [28]). This novel agenda in academia proactively pursues ideas to enhance the resilience and well-being of ecosystems and humans [26]. The hope behind Earth Stewardship is that, if people were to value places and especially forests for their own well-being, more sustainable pathways for ecosystem management would evolve with multiple economic, social and ecological benefits. This new approach to forests and other ecosystems deviates significantly from earlier mono-dimensional understandings of forests [26] that stressed the role of: (i) managed forests for sustainable timber production; (ii) natural forests for biodiversity conservation; or (iii) a/reforested areas for mitigating climate change such as through CDM A/R or REDD+.

\subsection{The Collaborative Turn in Global Landscapes Narratives}

According to the GPFLR, landscapes should be managed in an "integrated" way to achieve sustainable development. Integrated, in this respect, means that "natural resource use (forests, energy, agriculture, water, etc.), conservation and livelihoods" are equally pursued within a given area [4]. To create multiple benefits from landscapes for nature and society, collaboration between different stakeholders is vital. In line with the general procedural turn in world politics, GPFLR sees FLR mainly as "an active process that brings people together" [29]. Together with other international institutions, GPFLR strongly advocates stakeholder dialogue, via presentations or tools, to assure that not only governments but rather multiple actors together can identify, negotiate and implement FLR [1,29].

Through GPFLR, activities under the Bonn Challenge explicitly draw on the "Ten Principles for a Landscape Approach" [6] which in turn build on the work by Sayer et al. (2013) and were informed through an inclusive "intergovernmental and interinstitutional" negotiation process involving major groups within the GPFLR $[5,30]$. These principles define specified procedural means of integrating agricultural production and environmental conservation at the landscape level [30,31]. Most elements relate to enabling institutional and political frameworks, which ensure tenure and land-use rights, integrative land-use planning and inter-sectoral coordination as well as enhanced stakeholder participation and learning. These are achieved through integrative techniques of monitoring, capacity building and benefit sharing $[5,31]$.

Rather than defining concrete criteria for the well-being of ecosystems or humans, this FLR approach highlights the need to align different or competing interests such as conservation or production in the management of land at multiple scales and across various sectors. Collaborative multi-stakeholder processes bring together all relevant stakeholders to talk, plan and decide, thereby ensuring political buy-in from all different actors $[5,10,30]$. Many dialogue and exchange-oriented processes around the Bonn Challenge, including decision support tools such as the Restoration Opportunities Assessment Methodology (ROAM), are organized in line with this collaborative rationale. ROAM, for instance, helps countries contribute to the Bonn Challenge by identifying and prioritizing suitable land for restoration.

\subsection{A Place for Everyone's Well-Being}

Presenting and discussing FLR in this way builds on and further nourishes a narrative that there is a place for everyone in integrated landscapes. In addition to climate change adaptation, mitigation or livelihood related services, landscapes provide scope for high agricultural yields and corporate profits as well as conservation. Central to this idea of achieving multiple benefits within one landscape is the rationale of mosaic landscapes, to be complemented by wide-scale restoration. In mosaic landscapes, FLR is integrated in multiple parallel land use systems for forestry, wetlands, pasture, settlement or 
intensive agriculture. Large-scale restoration, by contrast, helps to achieve broader conservation targets in often remote areas where fewer people and hence competing interests are concerned $[4,5]$. In its communication, GPFLR employs a shared picture of these two complementary restoration approaches; reflecting the idea that achieving multiple objectives within a single landscape is possible [4].

\section{Theoretical Framework-Discourse Analysis}

Numerous researchers have discussed supposedly favorable or unfavorable conditions for successful forest project implementation. These studies often suggested that technical, financial, administrative or governance related issues such as limited seed funding or insecure tenure are decisive in explaining why forest projects fail or succeed [32]. Notwithstanding this seminal work, the varied practical experiences with forest policies and restoration in CDM A/R or REDD+, do not provide a definitive picture of the root causes of the practical under-utilization of FLR.

Complementary to factors related to institutional contexts, governance arrangements or market forces, more recent work by social constructivists offers promising corrective insights into why people reject restoring initiatives even when high economic incentives or supportive institutions are given (e.g., [33,34]). Discourse analytic scholars suggest that how relevant actors think and talk is highly illuminating of social phenomena [35]. "Words matter in policy and planning" [36] and several studies, e.g., case studies related to the Netherlands [37], Costa Rica [38] and South Korea [39], vividly illustrate the importance of language and meanings for implementing environmental policies.

In this paper, we draw on the work of Hajer, which defines discourse as "an ensemble of ideas, concepts, and categories through which meaning is given to social and physical phenomena, and which is produced and reproduced through an identifiable set of practices" ([34], p. 67). Discourse analysis is the primary methodological approach to unravelling what discourses or discursive structures underlie existing policy-making processes. By investigating the use of language and particularly ways of speaking ([35], p. 38), scholars can reconstruct the narrative foundations of all sorts of social phenomena, including FLR practices.

The pre-assumption is that problems, like their solutions, are narratively constructed through direct or strategic use of language, signs, symbols and metaphors [34]. Language is the key driver of change in policies. It can shift power balances and, hence, determines what policies or institutions are supported, established, changed or not changed [34]. Correspondingly, inadequate or absent policies can be seen as the result of discursive struggles between different groups of actors. Ultimately, as is highlighted by Thompson et al. (2011), specific policy tools, actors and solutions are often prioritized in policy-making while others are marginalized [40]. Through this lens of discursive domination and suppression, discourse analysis can help to better understand counterfactual or erratic behavior, such as local resistance to highly beneficial policy programs.

In the academic literature, three Meta-discourses have been identified in the context of forest policies, REDD+ and CDM: (i) Ecological Modernization; (ii) Green Governmentality; and (iii) Civic Environmentalism $[13,14,16]$. The Ecological Modernization and Green Governmentality perspectives draw attention to capitalist and techno-managerial understandings and stand in contrast to the discourse of Civic Environmentalism. The latter stresses the non-marketable values of forests and nature as well as the need to empower local actors as major agents for change. A radical version of this discourse categorically rejects political programs like REDD+ because of their suspected neo-colonialist intention to suppress countries of the South [41]. In practice, the Civic Environmentalism discourse is dominated by the two other symbiotic discourses which highlight cost-effective, highly synergistic "win-win" approaches (Ecological Modernization) to solve politically and scientifically tamable problems (Green Governmentality).

In this paper, we contribute to a better understanding of the underlying discursive structure and ongoing narrative struggles in the debates about Forest Landscape Restoration (FLR)—in comparison to existing discourses on afforestation and reforestation (A/R, CDM) or REDD+. Specifically, we aimed to identify what interpretations of FLR are advocated by different relevant stakeholders and to evaluate 
whether the global discourse around the Bonn Challenge is able to embrace and reconcile different applications of FLR. With this, our findings will help to avoid on-ground political resistance.

\section{Materials and Methods}

This paper employs discourse analysis to reconstruct the various meanings of FLR held by different actors at different policy levels. Discourse analysis focuses on all sorts of spoken or written statements and elaborates on different discursive constructions such as narratives, storylines or metaphors within a specific socio-historical context [34]. We follow the preferred interpretative approach to mapping out different storylines "to tease out the underlying perceptions, shared terms and concepts that actors use to give meaning to the integrated landscape approach discourse" ([19], p. 178).

Our analysis draws on methods like participatory observation and desk research. We investigate existing scientific analyses, reports and other documents such as policy or working papers on FLR by employing combined qualitative and quantitative content analysis [42]. To grasp discursive practices of different actors, we attended various workshops, side events and discussions about FLR, forest and land use between 2013 and 2017, e.g., in the context of IUFRO, UNFCCC and the Global Landscapes Forum (see Appendix A).

In addition, we conducted three helicopter interviews and several informal interviews with key informants from the Bonn Challenge, UNFCCC and academia. These interviews helped us to focus our research question, identify relevant events, implementation examples or potential addressees for the subsequent survey. To ensure anonymity, we refer to them as "Interview 1", "Interview 2" and so forth in the Results Section. To capture specific country perspectives on FLR we furthermore approached more than 500 actors from different countries, world regions and societal sectors with a survey between July and August 2017. The anonymous online-based structured survey in four different languages (English, Spanish, French and German) yielded 69 responses. Questions were mainly open-ended except for those covering demographic features and the relevance of different actor groups such as governments, banks, scientists, consultants or communities. For the latter, survey participants were asked to rank the relevance of different actor groups from 1 (very low) to 5 (very high). Overall, the sample covered a diversity of actor groups from 34 different countries with a more or less balanced representation of different world regions (see Table 1).

Table 1. Survey participant statistics: regions, affiliation, and sex.

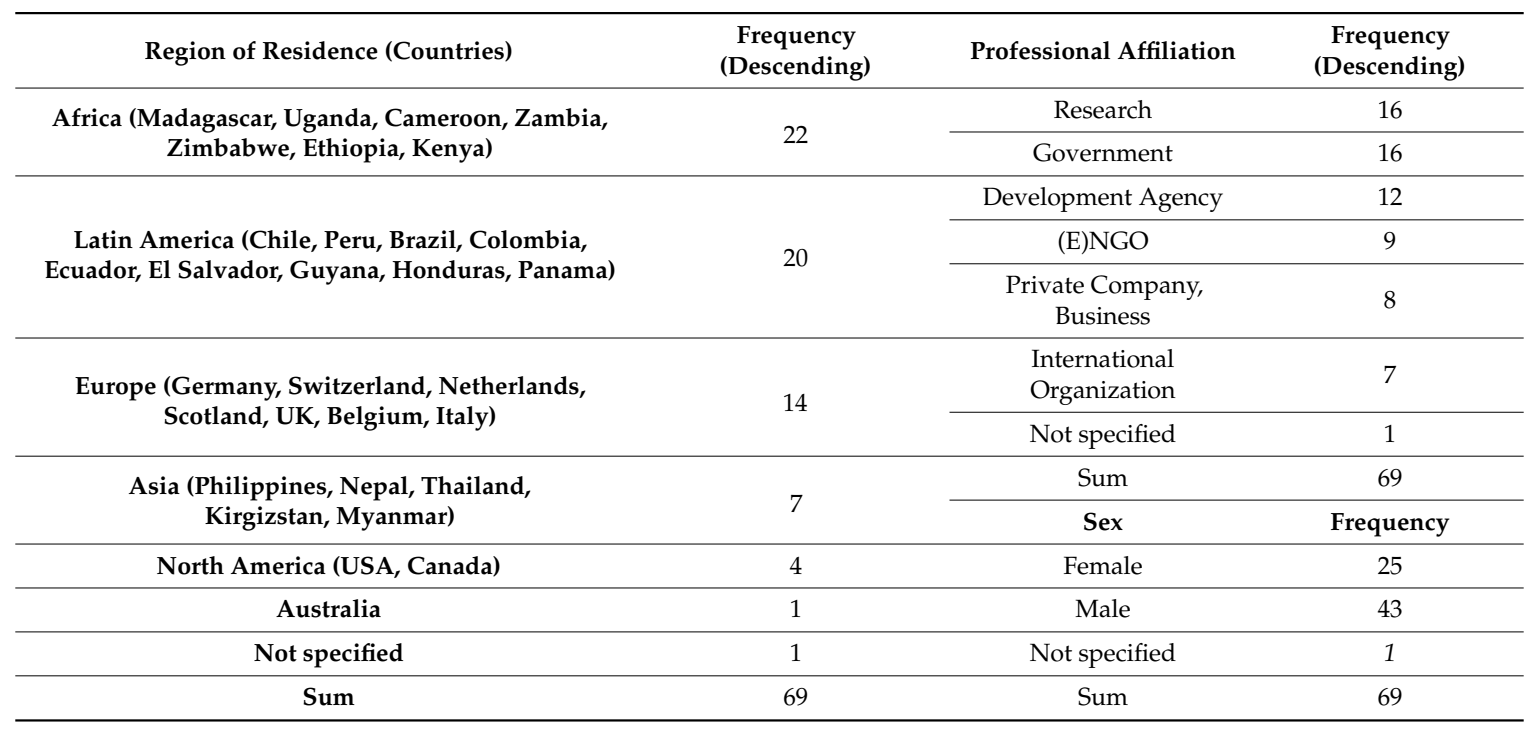

Two thirds were from developing countries in Africa, Asia and Latin America. Another third was from Europe, North America and Australia. In several countries, we found more than one 
respondent (e.g., Madagascar, 10; Chile, 7; Germany, 6; Uganda, 5; Brazil, Cameroon, Peru, and USA, 3; and Colombia, Netherlands, Nepal, Philippines, and Switzerland, 2). Concerning the different societal sectors and actor groups, research and governments were particularly well represented, followed by development agencies, NGO representatives, private companies and international organizations (IOs, see Table 1). For the sake of encouraging frank responses, the survey was anonymous and our references to interviews only mention country and affiliation.

To identify how distinct stakeholders understand FLR, we asked survey participants: (i) "How do you define forest (and) landscape restoration?" (ii) "What major achievements can be obtained through FLR?" (iii) "What are your major concerns about FLR?" (iv) "How relevant do you see diff. actors in FLR: national governments, local governments/communities, smallholders, multinational/development banks, private funds, multinational corporations, national companies, certification standards, technical consultants, research?" An open follow-up question ("Please specify your choice") helped us identify the underlying rationales behind the different rankings. (v) "What needs to be done politically to promote FLR?" Based on the survey answers, and enriched by insights from desk work, observation and interviews, we identified various narratives about FLR that are articulated by different actor groups.

All relevant statements were transcribed, coded and analyzed by means of content analysis employing the qualitative data analysis software MAXQDA version 11 (VERBI Software-Consult-Sozialforschung GmbH, Berlin, Germany). This yielded 3000 codings and 300 raw codes, which were further clustered and categorized in line with the five questions.

\section{Results}

In the following section, we describe key results from our analysis that help to identify distinct understandings held by relevant actor groups across different countries and regions. We expanded on storylines about FLR in line with the five survey questions related to: (1) FLR definition; (2) achievements; (3) concerns; (4) political solutions; and (5) relevant actors. With that, we could reconstruct relevant topics pursued by actors in various country contexts and to assess whether their ideas resonate well with those held in the context of the Bonn Challenge at global level. In this way, we can reveal contradictions and possible conflicts and develop suggestions as to how the Bonn Challenge may better accommodate and reconcile different views.

\subsection{FLR Definitions at National and Sub-National Levels}

When asked to define FLR and what it means to them, almost all survey respondents $(n=63)$ highlighted the ecological outcomes to be achieved. At the same time, almost as many respondents $(n=61)$ stressed socio-economic values. Moreover, a clear majority $(n=58)$ simultaneously pinpointed the importance of both ecological and socio-economic well-being. On a general level, views in specific country contexts appear to correspond very well with global ideas about FLR as an integrative approach to human and ecosystem well-being. Two respondents from a German business and Brazilian development agency even directly quoted the GPFLR definition. Four respondents (Madagascar, IO, Switzerland, research, Chile, government, Myanmar, development agency) referred to FLR in a way that reflected the procedural notion as held by GPFLR and the Bonn Challenge. They further noted that FLR is about a transparent learning process, adaptive management, multi-stakeholder participation and resilience for the sake of achieving "ecosystem and human well-being" (Myanmar, development agency).

Among the five respondents that highlighted only ecological well-being, four are from Chile (science (2), government, and civil society). This deviation of primarily envisioning "landscapes with original native forest species" (Chile, NGO, translated by authors) may be rooted in the fact that, in comparison to other countries, Chile does not face severe poverty problems but has experienced a dramatic destruction and loss of natural forests and soil erosion. By contrast, two other Chileans 
(private company, government) referred to neither ecological nor economic aspects, but rather highlighted the novel procedural, integrative or spatial aspects of FLR.

Moreover, two of the three interviewees that stressed mainly socio-economic well-being are government representatives from African countries (Madagascar, Uganda). The third was from Germany and displayed a fairly production-oriented view on natural resources throughout the questionnaire. On a very general level, country-based understandings of FLR resonate well with the purposefully very broad global notion. However, variation in what FLR means in concrete becomes clearer when investigating what actors expected to achieve with it.

\subsection{Desired Achievements through FLR at National and Sub-National Levels}

In a general sense, most actors aspired to the achievement of multiple benefits, or more explicitly multi-functionality, through FLR. In detail, however, there was variation in terms of exactly how different functions are understood by different people.

\subsubsection{Sustainable Rural Development}

"A key achievement of FLR is enhanced livelihood of the communities in that landscape" (Uganda, government). As in this quote, a large group of survey respondents $(n=30)$ expressed the view that FLR should address rural poverty and promote development, especially for local and forest-dependent people. Among concrete services that integrated landscapes deliver for people are food security, wood and energy for households and natural resource based incomes. Non-consumptive health and cultural benefits also play a role. Fourteen of the 30 respondents come from African countries, nine from developed countries (esp. Germany) and four from Asia. Only three out of twenty Latin American respondents shared this rural development focus. Moreover, only a very small number of respondents mentioned general economic needs of the (Green) economy, industry or investors, or suggested large-scale, plantation-based restoration. Very distinct notions of who should actually benefit from development, and even more so regarding the extent to which human development should be prioritized in comparison to ecological goals, were present in the sample.

\subsubsection{Biodiversity Conservation}

As already mentioned, ecosystem integrity is a key element of the meaning assigned by most respondents to FLR. A closer look at the 52 responses that refer to ecological functioning and integrity reveals the dominance of strong anthropocentric motives and concerns about livelihood and sustainable rural development over purely ecological concerns.

Although achieving biodiversity conservation through FLR was highlighted 22 times, it remains just one among many functions or services that ecosystems provide for humans. Water regulation and flow management were valued for the provisioning of drinking and irrigation water and flood protection. Nutrient recycling and prevention of soil erosion mattered for their agricultural and security utility, just as improved micro-climate and air quality were considered important in relation to human health. Particularly in African countries, the role of landscapes for food and livelihood was important. By contrast, only five out of 69 respondents spoke of restoring original forests or of conservation that pursued intrinsic goals such as saving species from extinction (Belgium, NGO) or maintaining wilderness (Switzerland, private reserve) by establishing large, fully functioning forests (Canada, science) or biodiversity corridors in landscapes (Nepal, development agency; and Chile, government). While biodiversity conservation for its own sake does not appear at the heart of most country-based discussions, it is at least an acknowledged by-product of FLR.

\subsubsection{Climate Change Mitigation}

In a lexical analysis that revealed how often certain terms or notions were mentioned, climate change placed among the top six topics of importance to respondents, alongside rural development, ecosystem services, landscapes, forests and local actors. When reflecting on different ecosystem 
services, respondents regularly referred to the role that forests played for climate change mitigation. Thirty-two respondents highlighted the sequestration of carbon as one of the most important ecosystem services ahead of other ecological functions: "A successful restoration process brings benefits to climate in form of carbon sequestration and storage, biodiversity benefits, other environmental benefits" (Belgium, NGO). This service was important to almost all Asian and two thirds of the African actors. By contrast, only one in three European or Latin American respondents mentioned it. However, several respondents were quite explicit that mitigation outcomes are pursued mainly to meet international, as opposed to local, objectives, e.g., under the Paris Agreement. They therefore serve primarily as vehicles for fulfilling political commitments or obtaining funding.

\subsubsection{Adaptation and Resilience}

Interestingly, the related topic of climate change adaptation as a major achievement of FLR received less prominent attention. In total, it was mentioned by only 17 respondents-comparably more often by Asian, African or North American respondents. Typically, adaptation was mentioned rather generally in conjunction with the climate change mitigation function. Where it was elaborated in more detail, adaptation was related to a broader understanding of resilient, integrated forest landscapes. Resilience in this view has an ecological as well as a socio-economic dimension, and the ecological component is to serve human needs: "Land use systems that are more resilient and sustainable in terms of environmental integrity bring greater and fairer social and economic benefits" (USA, development agency). Resilience was a concern in relation to strengthening communities and livelihoods, especially for respondents from the developing world. Five respondents from Africa and one from Asia see it as being highly important for water and food security or for the basis of life more generally. In addition, a few survey participants also referred to adaptation as a process of constant learning and adaptive management in line with the broader GPFLR understanding. Four respondents from Madagascar, USA, Germany and Myanmar stressed that in planning processes FLR should be built with high levels of flexibility and adaptive learning.

\subsubsection{Multi-Functionality and Trade-Offs}

Principally, FLR offers a broad set of social, economic and ecological benefits that may be accomplished simultaneously. When reconstructing statements regarding their actual subjective meanings, most environmental benefits that respondents highlighted are linked to anthropocentric motives like food, water purification or soil fertility. Achieving rural development preceded intrinsically ecological motives related to species conservation or ecosystem integrity. While there remains a place in landscapes for nature, such close-to-nature forests are rather "thought away" to unproductive or remote areas such as mountain ranges that cause no or little interference to agricultural activities or are envisioned in close vicinity to areas where direct benefits for people such as health, air purification or recreation are more direct. However, most respondents stress the balance between ecological functioning and human prosperity, yet without necessarily pursuing an image of perfect harmony between these ends. It is broadly acknowledged that "trade-offs between multiple targets" (Italy, research) always occur and as another respondent from the USA (development agency) figuratively put it, FLR is about achieving "[m]ulti-use areas being managed in a manner that maintains or enhances critical services and allows them to be sustainable in the long term. It is definitely not recreating the garden of Eden."

\subsection{Voiced Concerns about FLR in National and Sub-National Contexts (Problematization)}

When asked to state their concerns about FLR most respondents discussed such trade-offs and focused particularly on institutional, financial and cultural barriers to dealing with trade-offs. Trade-offs that were mentioned frequently included the fact that mitigation-oriented views on forests such as in REDD+ "will end up prioritizing carbon sequestration (fast growing trees) rather than true restoration" (Canadian scientist) or "possibly even switching biodiversity loss from one ecosystem to 
another" (Belgium, NGO). Such fears are in agreement with what concerned environmental NGOs have repeatedly argued in global discussions. They have suggested that the Bonn Challenge would indirectly trigger ecologically risky commercial monoculture plantations through illegal land grabbing in places wrongly identified as abandoned, which in turn could lead to environmental degradation and impoverishment $[5,43]$.

However, just one respondent fully embraced such an extreme position favoring profit-oriented, industrial plantation based production forests. Even where respondents stressed that landscapes should be economically viable and productive, they simultaneously noted that this needs be achieved through sustainable means and that large-scale plantations have to be avoided. Concrete worries that a highly productive use of landscapes principally compromises the carrying capacity of ecosystems were hardly mentioned. On the other hand, one actor portrayed human activities as a major "disturbance" for ecosystems, a position that extends even beyond radical market-critical positions in the Civic Environmentalism discourse in the literature. The Swiss private reserve owner highlighted the key intrinsic value of forests, which have to be protected urgently from "anthropogenic exploitation such as tourism, agriculture, science".

In fact, although less radically, numerous respondents voiced concerns that landscapes may not be managed sustainably with potentially negative impacts for the environment. The broad and very diverse set of political, socio-economic, financial, ecological, technical, conceptual, temporal and capacity related concerns is summarized in Table 2.

Table 2. Most important concerns as mentioned by survey participants.

\begin{tabular}{|c|c|}
\hline Types and Subtypes of Concerns Mentioned & Number of Respondents \\
\hline $\begin{array}{l}\text { Political concerns: } \\
\text { - weak/wrong policy framework (ministerial silos, tenure / rights recognition) } \\
\text { - vested political interests (short-sited, electoral cycles, power dynamics) } \\
\text { - top-down approach (international pledge/promises vs. implementation) } \\
\text { - insufficient inclusion of all relevant actors }\end{array}$ & 34 \\
\hline $\begin{array}{l}\text { Insufficient knowledge, technology and capacities } \\
\text { - incoherent/insufficient data or interdisciplinary models: "right" FLR practices } \\
\text { (species, lessons), landscape dynamics, culture and economics ("values"), human behavior } \\
\text { - unclear/contested definition and concepts (e.g., restoration, landscape) } \\
\text { - education, lack of awareness (public/stakeholders) } \\
\text { - insufficient monitoring/restoration capacity: technology transfer, management }\end{array}$ & 27 \\
\hline $\begin{array}{l}\text { Socio-economic concerns: } \\
\text { - attractive for, engaging private sector, esp. (short-term) economic viability } \\
\text { - high opportunity cost of unsustainable practices } \\
\text { - obsession with economic growth } \\
\text { - how rural production is organized generally }\end{array}$ & 16 \\
\hline $\begin{array}{l}\text { Ecological concerns: } \\
\text { - "bad restoration practices" } \\
\text { - large-scale, monoculture, genetically modified organisms (GMOs), invasive or } \\
\text { mal-adapted species } \\
\text { - high water, pesticide/fertilizer use, soil degradation } \\
\text { - competition (savanna, grassland), deforestation leakage } \\
\text { - low biodiversity and ecosystem functions in restored lands }\end{array}$ & 14 \\
\hline $\begin{array}{l}\text { Temporal concerns: } \\
\text { - missing long-term and adaptive perspective, time lag ("hungry now") } \\
\text { - time-intensive and costly participatory and agricultural (trees) practices }\end{array}$ & 12 \\
\hline $\begin{array}{l}\text { Financial concerns: } \\
\text { - sufficient, large-scale, long-term, public and private and domestic } \\
\text { - feasible business cases }\end{array}$ & 9 \\
\hline
\end{tabular}

Political and governance related aspects were highly salient. Specifically, quite a few respondents doubt governments' capacities and political will to successfully change land use, not least because of existing power dynamics and vested interests to stay in office rather than to change policies. "Politicians need to support conservation and environmental management [ ... ] This is unlikely however, with our current system of short term electoral cycles and an obsession with economic growth" (Guyana, research). Beyond that, respondents lamented unsuitable or poorly enforced legal 
frameworks, especially for securing tenure or land use rights. "The countries where these kinds of initiatives are implemented normally have a relatively weak legal and political framework (land rights, authorization processes, categorization and zoning of lands)" (Peru, development agency). Moreover, many respondents considered that technical-, knowledge- and capacity-related aspects threaten FLR success. The long list of technical- or knowledge-related issues covers conceptual controversies about, for instance, what restoration means in practice compared to in a strict scientific sense; gaps in data and models; or suitable restoration practices and (tree) species. Humans do not have the comprehensive understanding of the dynamics and human value of landscapes or of human behavior more generally, that would be necessary to find the best FLR solutions. Respondents' arguments were generally related to two issues: (1) a lack of awareness and valuation of nature; and (2) countries' lack of capacity for monitoring and planning. Additionally, insufficient education, capacity building and technology transfer remain major issues.

Although not as prominently stated as the aforementioned concerns, economic and financial aspects were mentioned by a range of respondents. Concerns covered general aspects such as whether FLR is principally attractive for engaging the private sector. In their view, the long time horizons of forest development lead to insufficient seed and long-term investments. The need to design FLR in adaptive and inclusive ways adds further to the required effort and costs associated with coordination. A few critical voices were concerned about the way that rural agricultural production and especially the economic system are organized: The "[u]nsustainable agricultural practices" and the "[e]ntrenched conceptualizations of development are inimical to the ethics of conservation" (Guyana, researcher).

Overall, it appears that concerns are not as pronounced as those known from discussions around the CDM or REDD+. Several interviewees noted that FLR focuses on abandoned and already degraded land. As such, it is unlikely that many concerns about environmental aspects will arise. At best, FLR can significantly reduce pressure on remaining natural forests by providing timber and non-timber products as alternatives (Interview 1) [30]. Madagascar is an example of this win-win situation that is often referenced in the literature as well as in our survey and interviews (e.g., Interview 2) [44]. One expert, however, sees a major risk in such a focus on sidelined lands on that basis that it may divert global attention and efforts away from protecting standing natural forests and "other" places in urgent need of rescue (Interview 4).

\subsection{Desired Solutions for FLR in National and Sub-National Contexts}

Solutions presented by respondents for addressing challenges to FLR implementation resonated strongly with how they problematized FLR (see Section 5.3). Notably, most of the statements centered on "policies \& politics, the financing and the technical capacity to realize it" (Peru, development agency) and often carried techno-scientific, regulatory and, partly, incentive focused notions (for an overview, see Table 3) resonating with the Green Governmentality and Ecological Modernization discourses in the literature.

Table 3. Possible solutions to address FLR challenges as mentioned by survey participants.

\begin{tabular}{lc}
\hline \multicolumn{1}{c}{ Mentioned Types and Subtypes of Solutions to Address FLR Challenges } & Number of Respondents \\
\hline Political solutions: & \\
- institution building, enabling pol. environment (cross-sectoral) & 56 \\
- collaborative approach: local engagement vs. regional/multilateral coordination & \\
- better policy implementation/law enforcement (less high level pledges) & \\
- political will and consideration of topic (at high/local level) & \\
\hline Financial solutions: & 23 \\
- provide (more) financial resources to achieve goals (across all relevant actors) & \\
- assure long-term financial support & \\
- make finances more accessible (esp. to small farmers) & \\
\hline
\end{tabular}


Table 3. Cont.

\begin{tabular}{|c|c|}
\hline Mentioned Types and Subtypes of Solutions to Address FLR Challenges & Number of Respondents \\
\hline $\begin{array}{l}\text { Technical solutions: } \\
\text { - capacity building, knowledge exchange } \\
\text { - improve research (e.g., valuation), optimize land use (agroforestry, intensification) } \\
\text { - better monitoring of (local) work } \\
\text { - clarify FLR terms, concepts, principles }\end{array}$ & 16 \\
\hline $\begin{array}{l}\text { Socio-cultural solutions: } \\
\text { - raise awareness (common entry point, value of nature, consumptive culture) } \\
\text { - support (school) education (locals, pupils, youth) } \\
\text { - strengthen youth associations } \\
\text { - facilitate major role for media }\end{array}$ & 13 \\
\hline $\begin{array}{l}\text { Economic solutions (market, viable): } \\
\text { - become economically viable } \\
\text { - conduct business in addition to primary production (processing, tourism, PES) } \\
\text { - ensure long-term employment } \\
\text { - link restored landscapes to local economies }\end{array}$ & 6 \\
\hline $\begin{array}{l}\text { Temporally oriented solutions: } \\
\text { - long-term plans beyond election periods tailored to future } \\
\text { climate/socio-economic scenarios }\end{array}$ & 3 \\
\hline
\end{tabular}

Political solutions were called for by almost all respondents. They highlighted the importance of the right institutional and regulatory frameworks as well as integrative policies and argued that these policies or laws should be better implemented and not just stated. For "closing the gap between pledges and implementation", spurring political will and high-level commitment as well as facilitating sectoral integration and coordination among ministries were identified as key measures in need of consideration. In contrast to political solutions in which governments play a central role, almost half of the respondents stressed that "[t]he interconnectedness and multidisciplinary nature of FLR requires coherent, well-coordinated, multi-stakeholder-participatory processes." (Philippines, IO). Collaboration with local actors is explicitly seen as indispensable for FLR in this context $(n=21)$.

Calls for governments to engage in more coherent and deliberate ways were often complemented by demands for enhanced capacities and knowledge. Clarifying terms, improving research and analytical models, better land use management techniques and monitoring were identified as important factors for translating the FLR concept into practice. In practical terms and for making integrated FLR approaches more profitable for smallholders who struggle with high opportunity costs, agroforestry systems were repeatedly presented as a viable technical approach to FLR. Agroforestry offered a perfect means for striking a balance between human and environmental needs. Assuring long-term, accessible and sufficient finance for a variety of actors is another approach pursued.

Reflecting on the role of awareness raising and education, especially for young people, just one in five respondents argued that the ways in which people and consumers value nature and landscapes need to change dramatically. For three respondents, it was another major priority to more proactively engage with long-term oriented approaches in planning that consider future climate or socio-economic scenarios.

\subsection{Relevant Actors in FLR}

When arguing about solutions, respondents repeatedly identified governments as the major agents for incentivizing the right behavior-through policy reforms $(n=14)$, especially of tenure and use rights $(n=9)$. At the same time, collaboration and processes that are inclusive of local actors were proposed. This position was reaffirmed when respondents were asked to rate the importance of different actors for FLR, including local and national governments, smallholders, researchers, consultants or development banks, companies and private funds.

In the survey, almost all respondents $(n=66)$ highlighted and evaluated the importance of local actors such as communities as high $(n=12)$ or very high $(n=54)$. Half of the respondents saw governments as playing the second most important role (see Figure 1). 
Although respondents, for different reasons, argued for involving a variety of actors through some sort of participation process, other actor groups like smallholders, science or certifying standards were emphasized far less than state governments or local communities. While the general profitability of production is not questioned, the state rather than the market is seen as holding high problem solution authority $(n=33)$, even for financial matters. It was considered that governments should provide the right institutional environment and incentives for better implementation. From the seven respondents who were very concerned about sustainable finance for FLR, just two actually wished to see more engagement of private sector actors such as big companies. Private, external investors are seen only in rare cases $(n=3)$ as the addressees of government programs.

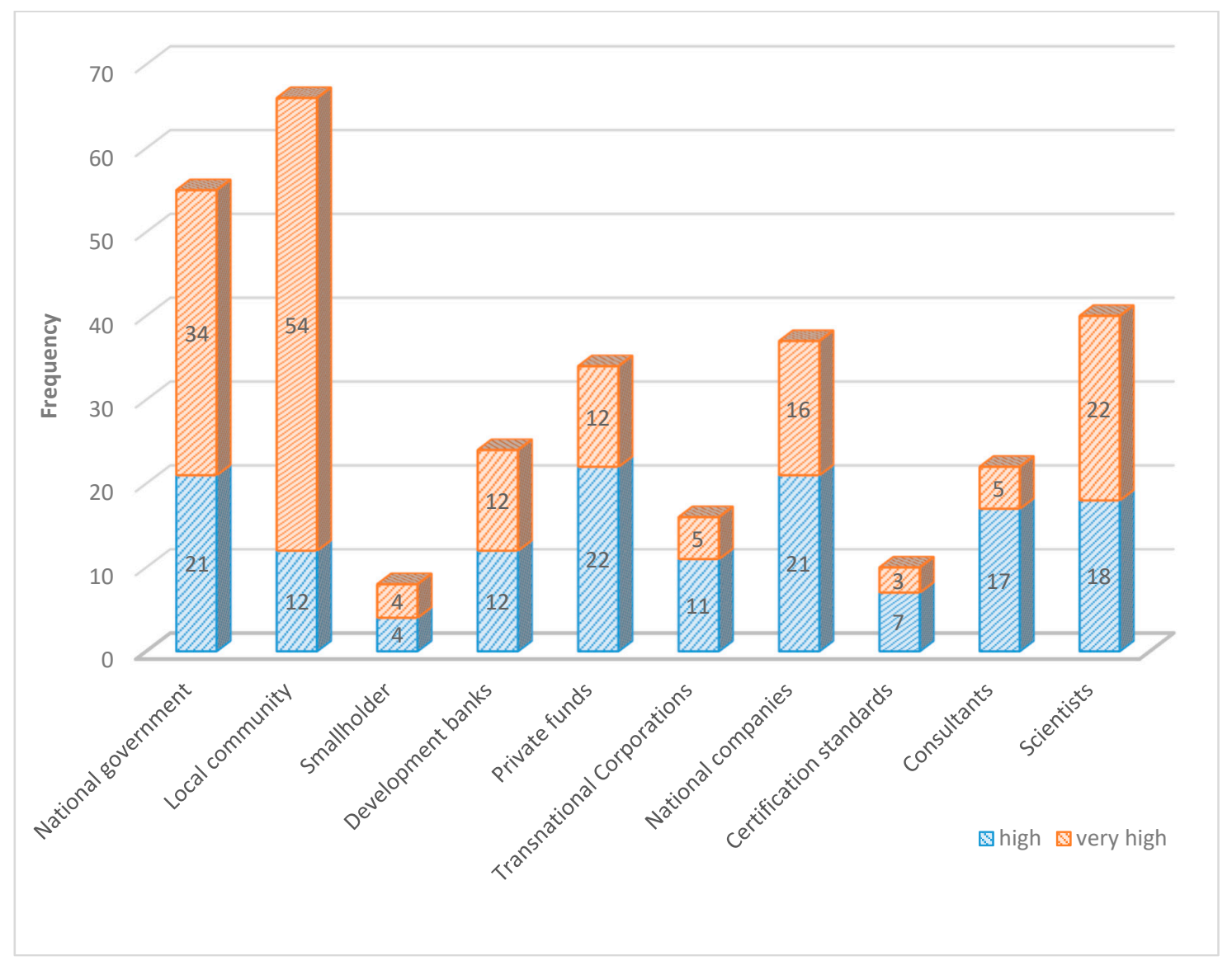

Figure 1. Importance of different actor groups in Forest Landscape Restoration (FLR) implementation.

Interestingly, smallholders (as actual agents on farmland) were evaluated as least important, not because respondents thought they had no right or say, but rather because they saw smallholders as just one among several relevant groups at the local level, including indigenous peoples and NGOs. The crucial aspect in this regard was that whole local communities rather than singular actors held authority in decisions about land. Beyond that, scientists may add the best available knowledge just as funds, companies and other investors contribute money and provide product markets. Complementary certification schemes assist monitoring and implementation.

\section{Discussion and Conclusions}

The Bonn Challenge and related initiatives have garnered unprecedented support from various countries and private actors. With a total of 160 million hectares pledged for restoration to date (February 2018), the global restoration goal for 2020 already appears to have been exceeded [2]. 
Occurring in the context of diplomatic relations between donor and recipient countries, these pledges are often expressions of intent rather than formal agreements, and thus still require translation into concrete actions (Interviews 5-7). For on-the-ground action, it seems crucial that the distinct ideas about FLR held by different actors are integrated and reconciled. The Bonn Challenge has been in existence for six years and only has three more to realize its goals. Against this backdrop, this paper contrasts the global understandings of Forest Landscape Restoration (FLR) with local and national notions. In this way we gain an insight into how similar or different various understandings are and whether the Bonn Challenge may evoke as much resistance as the CDM or REDD+ have before [12,45-47].

\subsection{The Global Discourse}

Our results suggest that the understanding of FLR as promoted by the Bonn Challenge and partners carries a strong procedural notion. The FLR concept is kept very broad, encompassing general principles such that it covers multiple scales and integrates actors in participatory and learning-oriented ways. In this way, the global discourse avoids prescription and leaves much discretion to country-based implementation in line with ideas of national sovereignty. As a voluntary partnership, the Bonn Challenge follows no rule book or concrete reporting or safeguard requirements comparable to those known from the CDM or REDD+ [48]. Such conceptual openness and context sensitivity helps to circumvent arduous diplomatic discussions typical of international conventions and avoids crippling ongoing political support and engagement (Interview 1).

The rather indefinite understanding of landscapes at "multiple scales" encapsulated in the FLR concept further contributes to this conceptual openness. Landscapes at multiple scales are not necessarily defined by national borders or other administrative units. They may encompass a single farm, a community, a watershed, a forest stand or any other humanly devised planning unit of land $[32,49,50]$. With such broadness, the global FLR concept remains susceptible to all sorts of narratives and respective management approaches to land, including Civic Environmentalist arguments, which are often sidelined in more market-oriented approaches such as CDM and REDD+ [14-16]. In this regard, FLR as pursued by the Bonn Challenge and partners has a strong reconciliatory quality and accommodates all sorts of societal perspectives. In practice, however, it depends highly on those implementing and interpreting FLR on the ground, i.e., on what they wish to achieve with it and whether they can actually agree on common ground.

\subsection{National and Subnational Discourses}

As the survey illustrated vividly, understandings of FLR vary dramatically between, as well as within, countries. Overall, however, most actors do not envision the practical embodiment of FLR as mono-functional, industrial monocultures, as is feared by some environmental NGOs [ 51,52$]$. Forest landscapes are more than just trees that sequester carbon or deliver timber. At the same time, FLR hardly means recovering original natural forests. Such extreme notions stressing the intrinsic value of nature and the need to protect wilderness from any human interference are rare-often grounded in experiences of dramatic historical forest loss as in Chile or Europe. By contrast, and particularly in African, developing countries, concerns about rural development and livelihoods are omnipresent. Correspondingly, landscapes are highly valued for the ecosystem services they provide for the benefit of humans and nature's intrinsic values become secondary whenever people starve or suffer.

Nonetheless, respondents hardly propagated purely market-based approaches to landscapes and were generally rather critical about industrial business models with more immediate economic benefits at the expense of sustainable long-term solutions-partly even questioning the obsession with economic growth in society. Accordingly, private sector operations require state or community control to avoid detrimental impacts on people and the environment.

Most notably, in many countries, a new view is evolving on the role of local people. As in reformist notions of Civic Environmentalism, they are perceived as indispensable for FLR, while governments are increasingly scrutinized regarding their capacity and will to bring about needed transformations. At the 
same time, recurring narratives around the techno-managerial state that objectify and disempower private (local) actors are also strong. In line with notions of Green Governmentality, governments are often portrayed as being in the driving seat, mainly to safeguard ecological interests and the public good; though problems associated with a lack of political will, coordination or enforcement persist. Other actor groups appear as mere bystanders, allowed to make their contribution-such as money, expertise or markets-yet always aligned with what states and/or local people as principle agents have planned.

In the views of our survey respondents and interviewees, FLR faces diverse trade-offs between different environmental as well as socio-economic benefits. This is further fueled by the fact that people naturally disagree about what should be achieved with FLR and actors are unequally equipped with the political, technical and financial means and rights to have their views respected. However, in prior discourse analyses of REDD+ or CDM [14-16], different actor positions have typically covered the whole spectrum from market-oriented understandings in Ecological Modernization over notions of techno-science in Green Governmentality to radical, emancipatory and ecological views in Civic Environmentalism. By comparison, the way in which FLR is currently discussed appears fairly centered and the concept is not nearly as controversial. Integration is a major rationale behind many narratives put forward by different actors. The unequivocal support for integrating local actor groups and for combining rural development motives with motives of conserving ecosystem services is unprecedented and offers a common discursive ground for most actors. In addition, the concept of mosaic restoration pursues the idea that there is a place for all land use types, offering a quasi-magical third rail between industrial agriculture and protected areas, between people and nature. With FLR targeted at degraded or abandoned land, the goal of conserving nature and undisturbed wilderness can easily be discursively sidelined or avoided in discussions.

\subsection{Implications for Implementation and the Future Role of the Bonn Challenge and Partners}

Despite its potential for achieving different climate, economic, development or biodiversity conservation objectives simultaneously [4-9], it is unlikely that practical FLR strikes an optimal balance between all possible claims or desires in society. In practice, quadruple wins rather present themselves as a suboptimal provisioning across different singular objectives. However, the ultimate gravity of possible trade-offs remains a political and empirical question depending on exactly who plans, implements and benefits from FLR in specific places. This situation needs to be taken seriously if large-scale emission reduction efforts, e.g., to fulfill international commitments under the Paris Agreement or the CBD, are to succeed in practice.

Against this backdrop and in light of our analytical insights, it remains particularly questionable whether and how FLR may reasonably integrate ideas of both top-down and bottom-up governance. The envisaged scenario of assigning planning authority to both local people and national governments simultaneously appears almost dialectical. Although it is a broadly supported view that organizing forest or climate policies in more participatory ways is critical [9], e.g., to assure political support and buy-in, an unreflected, discursive intermingling eventually risks new heated debates or-at worst-accelerates conflicts over rights, responsibilities and power. With its procedural notion, the Bonn Challenge has indeed pressed a "hot button" shaking existing power relations. It appears somewhat naïve that most identified challenges surrounding FLR mainly concern technical aspects or coordination rather than power imbalances. An open question is whether the Bonn Challenge and partners also hold responsibility for such newly evolving conflicts, which may, for instance, arise from the fact that formerly degraded land becomes fertile and profitable through FLR [52].

Likewise, one may ask whether the ongoing FLR initiatives can maintain the current momentum and whether the employed narrative can create common ground strong enough to prevent the concept from becoming a "floating signifier" — as happened with Sustainable Development $[53,54]$. Considering that most actors in the FLR community have been involved in REDD+ and that resistance to market-based instruments persists, it seems that FLR would greatly benefit from being further 
discursively delineated from REDD+ or CDM. Content wise, FLR has shifted away from a mere mitigation or market focus on forests, particularly with its focus on rural development and local people. In this regard, FLR may even provide new impulses for REDD+ implementation on the ground, thereby helping to lessen objection still faced by REDD+. At the same time, FLR is evolving in a broadly REDD+-shaped institutional environment where many countries have spent more than a decade designing forest policies in a very specific and mainly state-driven way.

Discursively orienting more progressively toward the inherent climate adaptation and development motives is another possibility for detaching from the poor reputation of REDD+ or CDM $[55,56]$. One major problem in the REDD+ and CDM discussions was their orientation towards carbon sequestration, grounded mainly in corporate and technical interventions [11-14]. Local resistance evolved because these initiatives disrespected and sidelined the local values given to biodiversity as well as rural development needs [12]. Moreover, although science and technology remain important for FLR, e.g., for monitoring or planning, it is as critical to pursue reflexive and collaborative learning processes in ever changing, complex and context-dependent landscapes. This can hardly be achieved through articulating expert opinion and top-down regulation alone $[57,58]$.

As discourse analytical scholars highlight, policy making itself can support processes of self-reflection needed for adaptive thinking. Any political community can be brought to "reflect on what they actually valued, who they were, where they came from and where (if anywhere) they wanted to go to collectively" ([37], p. 95). Partners around the Bonn Challenge may take on a decisive role in promoting and enabling such joint reflexive learning, considering that we lack experiences with and a blueprint solution for how to shape multi-stakeholder processes in a truly fair, integrative or inclusive manner. The same holds true for practical approaches to FLR where no single best solution is universally applicable for all contexts and times, not least because actors will always disagree about what constitutes a suitable approach to FLR.

For that, however, the Bonn Challenge and its supporting partners should proactively embrace the high power and value load of FLR. This implies acknowledging that compromises are often painful and lead to individually suboptimal or even frustrating solutions. With its strong narrative focus on governance processes that are inclusive of all relevant actors, the Bonn Challenge already indirectly supports more balanced negotiation processes and discursively empowers local and non-state actors. GPFLR as a partner network composed of and engaging with a variety of actors from different societal spheres and sectors—or the adjacent Global Landscape Forum-provide possible examples to follow. The challenge, however, will be to spread ideas of collaboration to places beyond abandoned and degraded sites, where high exploitative pressures and conservation hotspots collide.

Acknowledgments: This study was conducted with generous support from the German Ministry for Education and research (BMBF) as part of the project "TABEK-transformative increase in ambitions: the role of effective climate policy instruments" (sub-project: forest landscape restoration and private sector engagement). We thank all our interviewees for openly sharing their personal perspectives with us as well as the anonymous reviewers for their highly constructive feedback.

Author Contributions: This paper is the result of team work. Sabine Reinecke was mainly responsible for overall research idea, theoretical framework, research design, data analysis and interpretation, and drafting and discussing the text. Mareike Blum continuously contributed in data collection, literature research and interpretation. During revision, both authors were involved in straightening the empirical insights and drawing conclusions.

Conflicts of Interest: The authors declare no conflict of interest. 
Appendix A List of Relevant Workshops and Conferences Attended for Participatory Observation

\begin{tabular}{|c|c|}
\hline Date & Event \\
\hline 11-22 November 2013 & COP 19, Warsaw \\
\hline 16-17 November 2013 & Global Landscapes Forum, Warsaw \\
\hline 20 March 2014 & $\begin{array}{l}\text { Senat der Wirtschaft-Welt Wald Klima (World Forest Foundation), } \\
\text { Entscheiderkongress (decision makers conference), Berlin, Germany. } \\
\text { Für Wirtschaft und Gesellschaft. Mehr Wert durch Wald. (For Economy and Society. } \\
\text { More Value through Forest) }\end{array}$ \\
\hline 4-15 June 2014 & $\begin{array}{l}\text { SBSTA 40, Bonn } \\
\text { land use/restoration related side events and meetings }\end{array}$ \\
\hline 30 November-12 December 2015 & $\begin{array}{l}\text { COP 21/SBSTA } 41 \text {, Paris } \\
\text { land use/restoration related side events and meetings }\end{array}$ \\
\hline 5-6 December 2015 & $\begin{array}{l}\text { Global Landscapes Forum, Paris } \\
\text { restoration related discussion forums, launches etc. }\end{array}$ \\
\hline 6-13 November 2016 & $\begin{array}{l}\text { COP22/SBSTA } 43 \text {, Marrakesh } \\
\text { land use/restoration related side events and meetings }\end{array}$ \\
\hline 10-16 May 2017 & $\begin{array}{l}\text { SBSTA 46, BONN, selected side events and meetings: } \\
\text { land use/restoration related side events and meetings }\end{array}$ \\
\hline 6-9 June 2017 & $\begin{array}{l}\text { IUFRO's International Conference, Puerto Rico } \\
\text { Forest Landscape Restoration under Global Change }\end{array}$ \\
\hline 20 June 2017 & $\begin{array}{l}\text { International conference of the Amsterdam Group: Approaches for sustainable and } \\
\text { deforestation-free supply chains-A Multi-Stakeholder Conference for } \\
\text { cross-learning on examples of palm oil, cocoa and soy. } \\
\text { Berlin, organized by BMEL and BMZ }\end{array}$ \\
\hline 18-22 September 2017 & $\begin{array}{l}\text { IUFRO 125th Anniversary Congress 2017, Interconnecting Forests, Science and } \\
\text { People, Freiburg }\end{array}$ \\
\hline 6-16 November 2017 & $\begin{array}{l}\text { COP } 23 \text { Fiji in Bonn } \\
\text { land use/restoration related side events and meetings }\end{array}$ \\
\hline 19-20 December 2017 & Global Landscapes Forum, Bonn \\
\hline
\end{tabular}

\section{References}

1. Brancalion, P.H.S.; Pinto, S.R.; Pugliese, L.; Padovezi, A.; Rodrigues, R.R.; Calmon, M.; Mesquita, B. Governance innovations from a multi-stakeholder coalition to implement large-scale Forest Restoration in Brazil. World Dev. Perspect. 2016, 3, 15-17. [CrossRef]

2. Bonn Challenge. 2018. Available online: http:/ / www.bonnchallenge.org (accessed on 30 January 2018).

3. United Nations. FORESTS. New York Declaration on Forests, Actions Statements and Action Plans; Climate Summit: New York, NY, USA, 2012; Available online: http:/ / www.un.org/climatechange/summit/wpcontent/uploads / sites/2/2014/07/New-York-Declaration-on-Forest-\%E2\%80\%93-Action-Statementand-Action-Plan.pdf (accessed on 30 January 2018).

4. Global Partnership on Forest and Landscape Restoration (GPFLR): What Is Forest Landscape Restoration? 2018. Available online: http:/ / www.forestlandscaperestoration.org/forest-landscape-restoration (accessed on January 2018).

5. Pistorius, T.; Kiff, L. From a Biodiversity Perspective: Risks, Trade-Offs, and International Guidance for Forest Landscape Restoration; UNIQUE: Freiburg, Germany, 2017.

6. Pistorius, T.; Freiberg, H. From target to implementation: Perspectives for the international governance of forest landscape restoration. Forests 2014, 5, 482-497. [CrossRef]

7. Vira, B.; Wildburger, C.; Mansourian, S. Forests and Food: Addressing Hunger and Nutrition across Sustainable Landscapes; Open Book Publishers: Cambridge, UK, 2015.

8. Vallauri, D.; Aronson, J.; Dudley, N. An attempt to develop a framework for restoration planning. In Forest Restoration in Landscapes: Beyond Planting Trees; Mansourian, S., Vallauri, D., Dudley, N., Eds.; Springer: New York, NY, USA, 2005; pp. 65-70.

9. Ciccarese, L.; Mattsson, A.; Pettenella, D. Ecosystem services from forest restoration: Thinking ahead. New For. 2012, 43, 543-560. [CrossRef] 
10. World Resource Institute (WRI). Atlas of Forest and Landscape Restoration Opportunities-FLR Key Characteristics. 2017. Available online: http:/ / www.wri.org/resources/maps/atlas-forest-and-landscaperestoration-opportunities (accessed on 23 October 2017).

11. Smith, J. Afforestation and reforestation in the clean development mechanism of the Kyoto Protocol: Implications for forests and forest people. Int. J. Glob. Environ. Issues 2002, 2, 322. [CrossRef]

12. Gerber, J.-F. Conflicts over industrial tree plantations in the South: Who, how and why? Glob. Environ. Chang. 2011, 21, 165-176. [CrossRef]

13. Razak, S.A.; Son, Y.; Lee, W.-K.; Cho, Y.; Noh, N.J. Afforestation and reforestation with the clean development mechanism: Potentials, problems, and future directions. For. Sci. Technol. 2009, 5, 45-56. [CrossRef]

14. Bäckstrand, K.; Lövbrand, E. Planting Trees to Mitigate Climate Change: Contested Discourses of Ecological Modernization, Green Governmentality and Civic Environmentalism. Glob. Environ. Politics 2006, 6, 50-75. [CrossRef]

15. Bastakoti, R.R.; Davidsen, C. Framing REDD+ at National Level: Actors and Discourse around Nepal's Policy Debate. Forests 2017, 8, 57. [CrossRef]

16. Di Gregorio, M.; Brockhaus, M.; Cronin, T.; Muharrom, E.; Santoso, L.; Mardiah, S.; Büdenbender, M. Equity and REDD+ in the media: A comparative analysis of policy discourses. Ecol. Soc. 2013, 18, 39. [CrossRef]

17. Morris, A. Forestry and Land-Use Conflicts in Cuenca, Ecuador. Mt. Res. Dev. 1985, 5, 183-196. [CrossRef]

18. IUFRO. A Contribution to the Implementation of the Bonn Challenge. In Proceedings of the International Conference on Forest Landscape Restoration under Global Change, San Juan, Puerto Rico, 6-9 June 2017.

19. Nielsen, T.D. From REDD+ forests to green landscapes? Analyzing the emerging integrated landscape approach discourse in the UNFCCC. For. Policy Econ. 2016, 73, 177-184. [CrossRef]

20. Johann, E. Traditional forest management under the influence of science and industry: The story of the alpine cultural landscapes. For. Ecol. Manag. 2007, 249, 54-62. [CrossRef]

21. Grau, H.R.; Aide, T.M.; Zimmermann, J.K.; Thomlinson, J.R.; Helmer, E.; Zou, X. The Ecological Consequences of Socioeconomic and Land-Use Changes in Postagriculture Puerto Rico. BioScience 2003, 53, 1159-1168. [CrossRef]

22. Lugo, A. Restoration Outcomes: Decades Later, Input to IUFRO's International Conference on Forest Landscape Restoration under Global Change-A Contribution to the Implementation of the Bonn Challenge" in Puerto Rico, 6-9 June 2017. Available online: https:/ / www.iufro.org/download/file/27711/6474/16_ AL_Restoration_IUFRO_Workshop_pdf/ (accessed on 23 February 2018).

23. Society for Ecological Restoration International Science \& Policy Working Group. The SER International Primer on Ecological Restoration; Society for Ecological Restoration International: Tucson, AZ, USA, 2004; Available online: www.ser.org (accessed on 21 January 2018).

24. Lamb, D.; Stanturf, J.; Madsen, P. What Is Forest Landscape Restoration? In Forest Landscape Restoration: Integrating Natural and Social Sciences; Stanturf, J., Lamb, D., Madsen, P., Eds.; Springer: Dordrecht, The Netherlands, 2012; pp. 3-23.

25. Mansourian, S. Understanding the relationship between governance and forest landscape restoration. Conserv. Soc. 2016, 14, 267. [CrossRef]

26. Chazdon, R. Restoration Forestry: Challenges and Opprotunites for Forests, Foresters and Landscapes. In Proceedings of the 125th Anniversary IUFRO Conference, Freiburg, Germany, 22 September 2017; Available online: https: / www.youtube.com/watch?v=WcdgQL05klM?iframe=true\%20rel=0\&autoplay= $1 \&$ showinfo $=0$ (accessed on 23 October 2017).

27. Blum, M.; Reinecke, S. Towards a Role-Oriented Governance Approach: Insights from Eight Forest Climate Initatives. Forests 2017, 8. [CrossRef]

28. Chapin, F.S.; Power, M.E.; Pickett, S.T.A.; Freitag, A.; Reynolds, J.A.; Jackson, R.B.; Bartuska, A. Earth Stewardship: Science for action to sustain the human-earth system. Ecosphere 2011, 2, 89. [CrossRef]

29. Global Partnership on Forest and Landscape Restoration (GPFLR). Assessing National Potential for Landscape Restoration. A Briefing Note for Decision-Makers. Available online: http:/ / www.forestlandscaperestoration. org/sites/default/files/topic/assesing_national_potential_for_landscape_restoration.pdf (accessed on 7 February 2018). 
30. GPFLR. Ten Principles for a Landscape Approach to Reconciling Agriculture, Conservation, and Other Competing Land Uses. 2018. Available online: http:/ / www.forestlandscaperestoration.org/resource/tenprinciples-landscape-approach-reconciling-agriculture-conservation-and-other-competing- (accessed on 5 February 2018).

31. Sayer, J.; Sunderland, T.; Ghazoul, J.; Pfund, J.-L.; Sheil, D.; Meijaard, E.; Buck, L.E. Ten principles for a landscape approach to reconciling agriculture, conservation, and other competing land uses. Proc. Natl. Acad. Sci. USA 2013, 110, 8349-8356. [CrossRef] [PubMed]

32. Thomas, S.; Dargusch, P.; Harrison, S.; Herbohn, J. Why are there so few afforestation and reforestation Clean Development Mechanism projects? Land Use Policy 2010, 27, 880-887. [CrossRef]

33. Hajer, M.A. The Politics of Environmental Discourse: Ecological Modernization and the Policy Process; Oxford University Press: Oxford, UK, 1995.

34. Hajer, M.A. Doing discourse analysis: Coalitions, practices, meaning. In Words Matter in Policy and Planning: Discourse Theory and Method in Social Sciences; van den Brink, M., Metze, T., Eds.; Netherlands Geographical Studies: Utrecht, The Netherlands, 2006; Volume 344, pp. 65-74.

35. Foucault, M. The Archeology of Knowledge; Tavistock: London, UK, 1972.

36. Van den Brink, M.; Metze, T. Words Matter in Policy and Planning: Discourse Theory and Method in the Social Sciences; Koninklijk Nederlands Aardrijkskundig Genootschap: Utrecht, The Netherlands, 2006.

37. Hajer, M.A. Frame in the fields: Policymaking and the reinvention of politics. In Deliberative Policy Analysis: Understanding Governance in the Network Society; Hajer, M.A., Wagenaar, H., Eds.; Cambridge University Press: Cambridge, UK, 2003; pp. 88-112.

38. Louman, B. Factors that Affect Adoption of Tree Conservation and Planting Activities in Farms in Costa Rica. Input to IUFRO's International Conference on Forest Landscape Restoration under Global Change-A Contribution to the Implementation of the Bonn Challenge" in Puerto Rico, 6-9 June 2017. Available online: https:/ / www.iufro.org/download/file/27051/6474/14_BL_adoption_factors_Bastiaan_Louman_pptx/ (accessed on 23 October 2017).

39. Youn, Y.-C. Policy Integration for Reforestation in the Republic of Korea Input to IUFRO's International Conference on Forest Landscape Restoration under Global Change-A Contribution to the Implementation of the Bonn Challenge" in Puerto Rico, 6-9 June 2017, PPT. Available online: https: / /www.iufro.org/download/ file/27014/6474/01_YCY_ReforestationPolicyIntegration_YOUN_pptx/ (accessed on 30 January 2018).

40. Thompson, M.C.; Baruah, M.; Carr, E.R. Seeing REDD+ as a project of environmental governance. Environ. Sci. Policy 2011, 14, 100-110. [CrossRef]

41. Cabello, J.; Gilbertson, T. A colonial mechanism to enclose lands: A critical review of two REDD+-focused special issues. The atmosphere business. Ephemer. Theory Politics Organ. 2012, 12, 162-180.

42. Mayring, P. Kombination und Integration qualitativer und quantitativer Analyse. Forum Qual. Soz. $2001,2$. [CrossRef]

43. Global Rainforest Coalition: What's at Steak. Video Presentation on "Land Conflicts with Green Resources Mozambique". 2017. Available online: https:/ / www.youtube.com/watch?v=jPU9ydB4b2U (accessed on 23 October 2017).

44. Denier, L.; Scherr, S.; Shames, S.; Chatterton, P.; Hovani, L.; Stam, N. The Little Sustainable Landscapes Book; Global Canopy Programme: Oxford, UK, 2015.

45. Carbon Trade Watch. Protecting Carbon to Destroy Forests: Land Enclosures and REDD+. 2013. Available online: http:/ / www.carbontradewatch.org/downloads/publications/REDD_and_land-web.pdf (accessed on 30 January 2018).

46. Gilbertson, T. Carbon Pricing Report: A Critical Perspective for Community Resistance. 2017. Available online: http:/ / www.ienearth.org/wp-content/uploads/2017/11/Carbon-Pricing-A-Critical-Perspectivefor-Community-Resistance-Online-Version.pdf (accessed on 30 January 2018).

47. Lang, C. REDD: An Introduction. 2018. Available online: http://www.redd-monitor.org/redd-an-introduction/ (accessed on 30 January 2018).

48. Pistorius, T.; Carodenuto, S.; Wathum, G. Implementing Forest Landscape Restoration in Ethiopia. Forests 2017, 8, 61. [CrossRef]

49. McCarter, J.B.; Wilson, J.S.; Baker, P.J.; Moffett, J.L.; Oliver, C.D. Landscape Management through Integration of Existing Tools and Emerging Technologies. J. For. 1998, 96, 17-23. 
50. Pinto-Correia, T.; Gustavsson, R.; Pirnat, J. Bridging the Gap between Centrally Defined Policies and Local Decisions-Towards more Sensitive and Creative Rural Landscape Management. Landsc. Ecol. 2006, 21, 333-346. [CrossRef]

51. World Rainforest Movement. Press Release: FAO Definition must Recognize That Plantations Are Not Forests! 2017. Available online: http:/ / wrm.org.uy/actions-and-campaigns/press-release-fao-definitionmust-recognize-that-plantations-are-not-forests / (accessed on 5 January 2018).

52. Mansourian, S. Governance and Forest Landscape Restoration. Input to IUFRO's International Conference on Forest Landscape Restoration under Global Change-A Contribution to the Implementation of the Bonn Challenge" in Puerto Rico, 6-9 June 2017. Available online: https:/ / www.iufro.org/download/file/27042/ 6474/04_SM_Smansourian_Puerto_Rico_FLR_June_2017_pptx/ (accessed on 5 February 2018).

53. Fischer, K.; Hajdu, F. The importance of the will to improve: How 'sustainability' sidelined local livelihoods in a carbon-forestry investment in Uganda. J. Environ. Policy Plan. 2017, 1-14. [CrossRef]

54. Laclau, E.; Mouffe, C. Hegemony and Socialist Strategy: Towards a Radical Democratic Politics; Verso: Brooklyn, NY, USA, 2001.

55. Boyd, E. Governing the Clean Development Mechanism: Global Rhetoric versus Local Realities in Carbon Sequestration Projects. Environ. Plan. A 2009, 41, 2380-2395. [CrossRef]

56. Corbera, E. Problematizing REDD+ as an experiment in payments for ecosystem services. Curr. Opin. Environ. Sustain. 2012, 4, 612-619. [CrossRef]

57. Hoppe, R. Lost in translation. Boundary work in making climate change governable. In From Climate Change to Social Change: Perspectives on Science-Policy Interactions; Driessen, P., Leroy, P., van Viersen, W., Eds.; International Books: Utrecht, The Netherlands, 2010; pp. 109-130.

58. Voss, J.P.; Kemp, R. Sustainability and reflexive governance: Introduction. In Reflexive Governance for Sustainable Development; Voss, J.-P., Ed.; Edward Elgar: Cheltenham, UK, 2006; pp. 3-30.

(C) 2018 by the authors. Licensee MDPI, Basel, Switzerland. This article is an open access article distributed under the terms and conditions of the Creative Commons Attribution (CC BY) license (http:/ / creativecommons.org/licenses/by/4.0/). 